\title{
Pengaruh Transfusi Sel Darah Merah Terhadap Perubahan Kadar Kalium pada Pasien Thalassemia Mayor
}

Sacharissa Ardelia Larasati, Muhammad Riza

Bagian Ilmu Kesehatan Anak Fakultas Kedokteran Universitas Sebelas Maret/RSUD Dr. Moewardi, Surakarta

Latar belakang. Pada sebagian besar penderita thalassemia mayor, diindikasikan transfusi darah seumur hidup karena adanya proses hemolitik yang terjadi terus menerus. Pemberian produk darah mengandung beberapa unsur yang berisiko dan berpotensi menimbulkan efek samping. Metabolisme sel darah merah selama penyimpanan dapat menyebabkan kebocoran pada membran sel darah merah sehingga terjadi peningkatan kadar kalium.

Tujuan. Menganalisis pengaruh transfusi sel darah merah terhadap perubahan kadar kalium pada pasien thalassemia mayor.

Metode. Penelitian dilakukan di ruang perawatan hematologi anak RSUD Dr. Moewardi Surakarta pada bulan April-Mei 2018. Subjek penelitian sebanyak 50 pasien diambil secara konsekutif sesuai dengan kriteria inklusi dan ekslusi. Pasien thalassemia mayor yang mendapatkan transfusi darah terakhir pada saat rawat inap, dilakukan pemeriksaan kadar elektrolit kalium sebelum dan setelah transfusi sel darah merah. Data diolah dengan SPSS 17.0. Analisis untuk menilai hubungan kedua variabel menggunakan uji wilcoxon rank test.

Hasil. Didapatkan pengaruh transfusi sel darah merah terhadap perubahan kadar kalium pada pasien thalassemia mayor. Nilai rata-

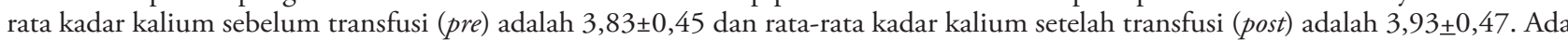
kecenderungan peningkatan kadar kalium sebesar 2,6\% $(\mathrm{p}=0,064)$ dan tidak ada yang menimbulkan hiperkalemia $(\mathrm{K}>5 \mathrm{mmol} / \mathrm{L})$. Kesimpulan. Terdapat pengaruh transfusi sel darah merah terhadap perubahan kadar kalium pada pasien thalassemia mayor, meskipun secara statistik tidak signifikan. Sari Pediatri 2019;21(4):241-5

Kata kunci: thalassemia, transfusi sel darah merah, kalium

\section{The Effect of Red Blood Cell Transfusion on Potassium Changes in Major Thalassemia Patients}

Sacharissa Ardelia Larasati, Muhammad Riza

Background. Lifelong blood transfusion is indicated in most thalassemia major patients due to the ongoing hemolytic process. Blood products contain some elements which have some risks and potentially cause side effects. Red blood cell metabolism during storage can result in leakage of red blood cell membranes leading to increased potassium level.

Objective. To analyze the effect of red blood cell transfusion on potassium changes in major thalassemia patients.

Methods. The study was conducted in the hematology ward of Dr. Moewardi Hospital Surakarta from April to May 2018. Fifty patients fulfilled the inclusion criteria were enrolled in our study. Major thalassemia patients who received the last blood transfusion at the time of hospitalization were examined for potassium electrolyte level before and after red blood cell transfusion. The data were processed with SPSS 17.0. The analysis to assess the correlation between the two variables used the wilcoxon rank test.

Results. Red blood cell transfusion affected on potassium changes in major thalassemia patients. The mean value of potassium level before transfusion was $3.83 \pm 0.45$ and the mean potassium level after transfusion was $3.93 \pm 0.47$. There was a tendency of increased potassium level of $2.6 \%(\mathrm{p}=0.064)$ without causing hyperkalemia $(\mathrm{K}>5 \mathrm{mmol} / \mathrm{L})$.

Conclusion. There was an effect of red blood cell transfusion on potassium changes in major thalassemia patients, although it is statistically insignificant. Sari Pediatri 2019;21(4):241-5

Keywords: thalassemia, red blood cell transfusion, potassium

Alamat korespondensi: Sacharissa Ardelia Larasati. Bagian Ilmu Kesehatan Anak Fakultas Kedokteran Universitas Sebelas Maret/RSUD Dr. Moewardi, Surakarta. Email: sacha_rissa22@yahoo.com 
T halassemia adalah penyakit herediter yang paling banyak ditemukan di seluruh dunia. ${ }^{1,2}$ Thalassemia diklasifikasi menjadi thalassemia $\alpha$ dan $\beta .^{3}$ Secara klinis, thalassemia dibagi menjadi thalassemia mayor (sangat tergantung pada transfusi), thalassemia minor/karier (tanpa gejala), dan thalassemia intermedia. Klasifikasi ini memiliki implikasi klinis dalam diagnosis dan tata laksana. Diagnosis thalassemia ditegakkan dari pemeriksaan klinis dan laboratorium untuk mengidentifikasikan adanya gangguan sintesis rantai globin. ${ }^{4}$

Transfusi dapat mengoreksi anemia, menekan eritropoiesis, mencegah hipoksia kronis, splenomegali, dan memperpanjang usia hidup pasien thalassemia mayor. Komplikasi tersering akibat transfusi berulang adalah penumpukan besi yang dapat dicegah dengan pemberian kelasi besi yang adekuat. ${ }^{5}$ Transfusi mengakibatkan peningkatan kadar kalium yang disebabkan oleh proses hemolisis sel darah merah dalam unit transfusi sel darah merah. ${ }^{6}$

Akumulasi produk dari metabolisme sel darah merah mengakibatkan perubahan biokimiawi pada unit transfusi sel darah merah, salah satunya terjadi peningkatan kadar kalium. ${ }^{7}$ Perubahan kadar kalium pada anak akibat transfusi masih jarang dibahas dan mungkin atau tidak mempunyai makna klinis. ${ }^{8}$

Penelitian mengenai tatalaksana hiperkalemia akibat transfusi telah banyak dibahas, namun untuk praktek sehari-hari perubahan kadar kalium akibat transfusi masih belum banyak dibahas. ${ }^{9}$

\section{Metode}

Desain observasional analitik digunakan untuk menganalisis hubungan antara pemberian transfusi darah dengan peningkatan kadar kalium pada pasien thalassemia mayor yang menerima transfusi sel darah merah. Penelitian dilakukan di ruang perawatan hematologi anak RSUD Dr. Moewardi Surakarta bulan April-Mei 2018. Populasi sasaran adalah semua pasien thalassemia beta mayor berusia 2 tahun sampai dengan 18 tahun. Populasi terjangkau adalah pasien thalassemia beta mayor berusia 2 tahun sampai dengan 18 tahun yang dirawat di ruang perawatan hematologi anak RSUD dr. Moewardi Surakarta bulan Mei 2018.

Subjek penelitian sebanyak 50 pasien diambil secara konsekutif sesuai dengan kriteria inklusi dan ekslusi. Kriteria inklusi adalah pasien berusia 2 - 18 tahun terdiagnosis thalassemia mayor berdasarkan gejala klinis dan pemeriksaan $\mathrm{Hb}$ elektroforesis, orangtua atau wali bersedia menandatangani lembar persetujuan mengikuti penelitian. Kriteria eksklusi adalah pasien dengan kelainan yang dapat menjadi faktor risiko terhadap kejadian hiperkalemia, seperti gangguan fungsi ginjal. Subjek penelitian dikelompokkan berdasarkan usia, jenis kelamin, kadar feritin, dan jumlah transfusi sel darah merah yang diterima. Pasien yang memenuhi kriteria penelitian, orangtua atau wali diminta menandatangani formulir persetujuan ikut serta dalam penelitian dan mengisi formulir penelitian. Pasien thalassemia mayor yang mendapatkan transfusi sel darah merah pada rawat inap yang terakhir dilakukan pemeriksaan kadar elektrolit kalium sebelum dan setelah transfusi sel darah merah. Hasil yang didapat dilakukan analisis secara statistika apakah terdapat pengaruh transfusi sel darah merah terhadap perubahan kadar kalium pada pasien thalassemia mayor.

\section{Hasil}

Berdasarkan data penelitian didapatkan deskripsi karakteristik sebagai berikut.

Tabel 1 merupakan data karakteristik dasar penelitian. Pasien thalassemia mayor terbanyak antara rentang usia usia 5-10 tahun $(46,0 \%)$ dan paling sedikit dengan usia $<5$ tahun $(10,0 \%)$. Jenis kelamin perempuan $(54,0 \%)$ lebih banyak dibanding lelaki $(46,0 \%)$. Rata-rata kadar ferritin pasien adalah $2741,88 \pm 1654,98$ dengan mayoritas pasien dengan kadar ferritin $\geq 1200(82,0 \%)$, dan kadar ferritin $<1200(18,0 \%)$. Pasien mayoritas menerima transfusi sebanyak 2 kantong $(44,0 \%)$ dan paling sedikit 4 kantong $(4,0 \%)$. Rata-rata kadar kalium pasien sebelum transfusi sebesar $3,83 \pm 0,45 \mathrm{mmol} / \mathrm{L}$.

Dari tabel 2 diketahui bahwa nilai median kadar kalium sebelum transfusi (pre) adalah 3,80 mmol/L $(2,30-4,90)$ dan nilai median kadar kalium setelah transfusi (post) adalah 3,90 mmol/L (2,30-4,80). Hasil penelitian juga menunjukkan bahwa terdapat 14 pasien thalassemia mayor yang mengalami penurunan kadar kalium, 31 pasien yang mengalami peningkatan kadar kalium, dan 5 pasien yang tidak mengalami perubahan. Dengan demikian, terdapat kecenderungan bahwa setelah transfusi terjadi peningkatan kadar 
Sacharissa Ardelia dkk: Pengaruh transfusi sel darah merah terhadap perubahan kadar kalium pada thalassemia mayor

Tabel 1. Karakteristik dasar subjek penelitian

\begin{tabular}{lcccc}
\hline Variabel & Frekuensi (n) & Persentase (\%) & Rerata & SD \\
\hline Usia (tahun) & & & 10,27 & 4,46 \\
$\quad<5$ & 5 & 10,0 & & \\
$5-10$ & 23 & 46,0 & & \\
$\quad 11-18$ & 22 & 44,0 & & \\
Jenis kelamin & & & & \\
$\quad$ Lelaki & 23 & 46,0 & & \\
$\quad$ Perempuan & 27 & 54,0 & & 1654,98 \\
Feritin & & & 2741,88 & \\
$<1200$ & 9 & 18,0 & & \\
$\geq 1200$ & 41 & 82,0 & & \\
Jumlah transfusi & & & & \\
1 kantong & 15 & 30,0 & & \\
2 kantong & 22 & 44,0 & & \\
3 kantong & 11 & 22,0 & & \\
$\quad 4$ kantong & 2 & 4,0 & & \\
Kalium Pre & & & 3,83 & 0,45 \\
\hline
\end{tabular}

Tabel 2. Kadar kalium sebelum dan setelah transfusi darah pada pasien thalassemia mayor

\begin{tabular}{lccc}
\hline Kalium & Median $($ min-max $)$ & Mean \pm SD & P \\
\hline Sebelum transfusi & $3,80(2,30-4,90)$ & $3,83 \pm 0,45$ & 0,064 \\
Setelah transfusi & $3,90(2,30-4,80)$ & $3,93 \pm 0,47$ & \\
\hline
\end{tabular}

Keterangan: Uji wilcoxon rank test

Tabel 3. Hubungan perubahan kadar kalium dengan usia, kadar feritin, dan jumlah transfusi

\begin{tabular}{lcc}
\hline \multirow{2}{*}{ Variabel } & \multicolumn{2}{c}{ Perubahan kadar kalium } \\
\cline { 2 - 3 } & $\mathrm{r}$ & $\mathrm{p}$ \\
\hline Usia & $-0,239$ & 0,093 \\
Kadar feritin & 0,105 & 0,468 \\
Jumlah transfusi & $-0,173$ & 0,230 \\
\hline
\end{tabular}

kalium sebesar 2,6\%. Hasil uji statistik didapatkan nilai $\mathrm{p}=0,064(\mathrm{p}>0,05)$ yang berarti bahwa transfusi darah tidak berpengaruh signifikan terhadap kejadian peningkatan kadar kalium.

Tabel 3 menunjukkan bahwa usia memiliki korelasi negatif dalam kategori lemah $(r=-0,239)$ terhadap perubahan kadar kalium. Semakin tua usia pasien maka kadar kalium cenderung mengalami penurunan. Akan tetapi, hasil uji statistik didapatkan nilai $\mathrm{p}=0,093$ ( $p>0,05)$ yang berarti bahwa tidak terdapat hubungan yang signifikan antara usia dengan kadar kalium.

Kadar feritin memiliki korelasi positif dalam kategori sangat lemah $(r=0,105)$ terhadap perubahan kadar kalium. Semakin tinggi kadar feritin maka kadar kalium cenderung mengalami peningkatan. Akan tetapi, hasil uji statistik didapatkan nilai $\mathrm{p}=0,468(\mathrm{p}>0,05)$ yang berarti bahwa tidak terdapat hubungan yang signifikan antara kadar feritin dengan kadar kalium.

Jumlah transfusi memiliki korelasi negatif dalam kategori sangat lemah $(r=-0,173)$ terhadap perubahan kadar kalium. Semakin banyak kantong transfusi maka kadar kalium cenderung mengalami penurunan. Akan tetapi, hasil uji statistik didapatkan nilai $\mathrm{p}=0,230$ ( $p>0,05)$ yang berarti bahwa tidak terdapat hubungan yang signifikan antara jumlah transfusi dengan kadar kalium. 


\section{Pembahasan}

Pasien thalassemia paling banyak didapatkan pada usia 5-10 tahun ( 46,0\%) dan paling sedikit usia $<5$ tahun $(10,0 \%)$ dengan rata-rata usia $10,27 \pm 4,46$ tahun. Hasil penelitian ini sesuai dengan penelitian Agouzal dkk ${ }^{11}$ yang melaporkan bahwa distribusi jumlah pasien thalassemia terbanyak didapatkan pada usia 5-10 tahun dengan rata-rata usia $10 \pm 5$ tahun. Pasien thalassemia mayor dengan jenis kelamin perempuan didapatkan sebesar $54,0 \%$, sedangkan yang berjenis kelamin lelaki sebesar 46,0\%. Penelitian ini sejalan dengan penelitian Shahramian $\mathrm{dkk}^{12}$ yang melaporkan bahwa perempuan (55\%) lebih banyak dibanding lelaki (45\%).

Hasil penelitian juga menunjukkan bahwa terdapat $31(62 \%)$ pasien yang mengalami peningkatan kadar kalium setelah transfusi, peningkatan kadar kalium berkisar antara 0,1-0,9 mmol/L, dengan kadar kalium tertinggi $4,8 \mathrm{mmol} / \mathrm{L}$. Dengan demikian, terdapat kecenderungan peningkatan kadar kalium sebesar 2,6\% dan tidak ada yang menimbulkan hiperkalemia $(\mathrm{K}>5$ $\mathrm{mmol} / \mathrm{L}$ ). Berdasarkan hasil uji statistik, didapatkan bahwatransfusi darah tidak berpengaruh bermakna terhadap kejadian peningkatan kadar kalium. Menurut Karim dkk, ${ }^{13}$ kadar kalium didapatkan lebih tinggi pada pasien thalassemia setelah transfusi, tetapi perbedaan kadar kalium ini tidak bermakna secara statistik. Temuan ini serupa dengan hasil dari penelitian kami. Sementara itu, penelitian Olson ${ }^{9}$ melaporkan bahwa terdapat perbedaan kadar kalium antara yang dibandingkan dari sebelum transfusi dengan 1 jam setelah transfusi, yaitu berkisar adalah $-0,5$ hingga $0,5 \mathrm{mmol} / \mathrm{L}$. Rata-rata perubahannya adalah $+0,08$ $\mathrm{mmol} / \mathrm{L}$. Namun, perubahan tersebut tidak ada yang menimbulkan kejadian hiperkalemia.

Adly $\mathrm{dkk}^{14}$ melaporkan korelasi positif yang bermakna antara kadar feritin dan indeks transfusi. Hal tersebut sesuai dengan penelitian lain, yang melaporkan bahwa peningkatan jumlah transfusi darah dikaitkan dengan peningkatan kadar feritin. Jumlah transfusi darah berhubungan dengan peningkatan kadar kalium. Hal ini terjadi akibat hemolisis sel darah merah pada unit darah simpan yang di transfusi ke pasien karena kalium cenderung bocor dari sel darah merah ke plasma darah. Hasil penelitian tersebut sesuai dengan penelitian kami karena didapatkan korelasi positif dalam kategori sangat lemah antara kadar feritin terhadap perubahan kadar kalium. Semakin tinggi kadar feritin maka kadar kalium cenderung mengalami peningkatan. Akan tetapi, berdasarkan hasil uji statistik tidak terdapat hubungan yang bermakna antara kadar feritin dengan kadar kalium.

Terdapat beberapa penelitian yang melaporkan kejadian hiperkalemia setelah transfusi pada pasien anak, seperti pada penelitian Dani ${ }^{15}$ yang melaporkan bahwa semakin banyak volume darah yang diterima, semakin banyak peningkatan kalium. Sebaliknya, dalam penelitian ini, jumlah transfusi memiliki korelasi negatif dalam kategori sangat lemah terhadap perubahan kadar kalium. Semakin banyak kantong transfusi maka kadar kalium cenderung mengalami penurunan.

Kelemahan penelitian ini adalah jumlah sampel terlalu kecil. Selain itu, tidak dilakukan analisis usia unit darah simpan. Peningkatan kadar kalium terjadi pada pasien dengan hemolisis sel darah merah, yang dapat terjadi pada unit darah simpan yang ditransfusi ke pasien karena kalium cenderung bocor keluar dari sel darah merah dalam unit darah simpan. Serta tidak dilakukan analisis diet pada pasien sehingga kita tidak bisa mengetahui berapa besaran asupan kalium yang didapatkan dari makanan.

\section{Kesimpulan}

Didapatkan pengaruh transfusi sel darah merah terhadap perubahan kadar kalium pada pasien thalassemia mayor meskipun secara statistik tidak bermakna $(\mathrm{p}=0,064)$.

\section{Daftar pustaka}

1. Krishnan N, Ravalya SG, Nazia SK. Management of thalassemia. Int Res J Pharm 2013;4:1-3.

2. DeBaun MR, Frei-Jones MJ, Vichinsky EP. Thalassemia syndromes. Dalam: Kliegman RM, Stanton BF, Schor NF, St. Geme III JW, Behrman RE, penyunting. Nelson textbook of pediatrics. Edisi ke-20. Philadelphia: Elsevier; 2016.h.2349-53.

3. Rachmilewitz EA dan Giardina PJ. How i treat thalassemia. Blood 2011;118:3479-88.

4. Sudarmanto B, Mudrik T, Sumantri AG. Transfusi darah dan transplantasi. Dalam: Permono B, Sutaryo, Ugrasena IDG, Windiastuti E, Abdulsalam M, penyunting. Buku ajar hematologi-onkologi anak. Jakarta: Badan penerbit IDAI; 2012.h.217-26.

5. Cao A dan Galanello R. Beta-thalassemia. Gen Med 
2010;12:61-76.

6. Al-Samarrai AH, Adaay MH, Al-Tikriti KA, dkk. Evaluation of some essential element level in thalassemia major patient in Mosul District, Iraq. Saudi Med J 2008;29:94-7.

7. Uvizl R, Klementa B, Adamus M, dkk. Biochemical changes in the patient's plasma after red blood cell transfusion. Signa vitae 2011;6:64-71.

8. Smith HM, Farrow SJ, Ackerman JD, dkk. Cardiac arrest associated with hyperkalemia during red blood cell transfusion: a case series. Anest Analg 2008;106:1062-9.

9. Olson J, Talekar M, Sachdev M, dkk. Potassium changes associated with blood transfusion in pediatric patients. Am J Clin Pathol 2013;139:800-5.

10. Hess JR. Conventional blood banking and blood component storage regulation: opportunities for improvement. Blood Transfus 2010;8:9-15.

11. Agouzal M, Arfaoui A, Quyou A, dkk. Beta thalassemia major: the moroccan experience. J Pub Health Epidemiol 2010;2:25-8.

12. Shahramian I, Razzaghian M, Ramazani AA, dkk. The correlation between troponin and ferritin serum levels in the patients with major beta-thalassemia. Int Cardiovasc Res J 2013;7:51-5.

13. Karim F, Ismail, Hasan M, dkk. Hematological and biochemical status of beta-thalassemia major patients in bangladesh: a comparative analysis. Int J Hematol Oncol Stem Cell Res 2017;10:7-12.

14. Adly AAM, Toaima DN, Mohamed NR, dkk. Subclinical renal abnormalities in young thalassemia major and intermedia patients and its relation to chelation therapy. The Egypt J Med Hum Gen 2014;15:369-77.

15. Dani C, Perugi S, Benuzzi A, dkk. Effects of red blood cell transfusions during the first week of life on acid-base, glucose, and electrolytes in preterm neonates. Transfusion 2008;48:2302-7. 